\title{
Evaluasi Pelaksanaan Pembelajaran Daring Pada Masa Pandemi COVID-19 Di SD Islam Terpadu
}

\author{
Alexon \\ Fakultas Keguruan dan Ilmu Pendidikan, Universitas Bengkulu, Bengkulu \\ alexon@unib.ac.id

\section{Wachidi} \\ Fakultas Keguruan dan Ilmu Pendidikan, Universitas Bengkulu, Bengkulu \\ wachidi@unib.ac.id \\ Windayani \\ Fakultas Keguruan dan Ilmu Pendidikan, Universitas Bengkulu, Bengkulu \\ ywinda389@yahoo.co.id
}

\begin{abstract}
This research aimed to evaluate the implementation of online learning during the COVID-19 pandemic in terms of the context aspect, Input aspect,Process aspect, and Product aspect. Data collection techniques with online questionnaires through Google Forms and documentation. The samples of this research were 29 teachers, 69 students, and 68 parents from grades 4-6 SDIT Hidayatullah Bengkulu City. The evaluation used the CIPP model and analyzed descriptively quantitatively by calculating the mean. The conclusions of this research were: (1) in terms of context, online learning during the COVID-19 pandemic at SDIT Hidayatullah Bengkulu City was very well done, (2) in terms of input, online learning during the COVID-19 pandemic SDIT Hidayatullah Bengkulu City was well implemented, (3) in terms of Process aspect, online learning during the COVID-19 pandemic SDIT Hidayatullah Bengkulu City was carried out well, (4) in terms of the Product, online learning during the COVID-19 pandemic SDIT Hidayatullah Bengkulu City was quite well done.
\end{abstract}

Keywords: online learning, CIPP evaluation model, COVID-19

\section{Pendahuluan}

Pandemi COVID-19 memberikan dampak pada pada banyak pihak, kondisi ini sudah merambah pada dunia pendidikan, pemerintah pusat sampai pada tingkat daerah memberikan kebijakan untuk meliburkan seluruh lembaga pendidikan. Hal ini dilakukan sebagai upaya mencegah meluasnya penularan COVID-19 . Kebijakan lockdown atau karantina dilakukan sebagai upaya mengurangi interaksi banyak orang yang dapat memberi akses pada penyebaran virus corona. Kebijakan yang diambil oleh banyak negara termasuk Indonesia dengan meliburkan seluruh aktivitas pendidikan, membuat pemerintah dan lembaga terkait harus menghadirkan alternatif proses pendidikan bagi siswa maupun mahasiswa yang tidak bisa melaksanakan proses pendidikan pada lembaga pendidikan. Hal ini didukung oleh Surat Edaran Nomor 4 Tahun 2020 tentang Pelaksanaan Kegiatan pendidikan Dalam Masa Darurat Penyebaran Corona Virus Disease (COVID-19) dalam format PDF yang ditandatangani oleh Menteri Pendidikan dan Kebudayaan Nadiem Makarim pada tanggal 24 Maret 2020. Prinsip yang diterapkan dalam kebijakan masa pandemi COVID-19 adalah "kesehatan dan keselamatan siswa, guru, tenaga kependidikan, keluarga, dan masyarakat merupakna prioritas utama dalam menetapkan kebijakan pembelajaran.” 
Sekolah Dasar merupakan salah satu jenjang pendidikan yang merasakan dampak pandemi COVID-19. Sekolah mulai mengubah strategi pembelajaran yang awalnya adalah tatap muka diubah menjadi pembelajaran non-tatap muka atau istilahnya Belajar Dari Rumah (BDR) yang biasa disebut juga Pembelajaran Jarak Jauh (PJJ) atau daring. Berbagai model pembelajaran dapat digunakan oleh guru untuk membantu siswa belajar dari rumah. Pemerintah menyediakan berbagai aplikasi pembelajaran yang dapat diakses dan digunakan oleh guru dan siswa. Menurut Arsyad (2011: 54), media pembelajaran online atau sering disebut dengan e-learning merupakan media penunjang pendidikan dan bukan sebagai media pengganti pendidikan. Prosesnya e-learning sebagai media distance learning menciptakan paradigma baru, yakni peran guru yang lebih bersifat "fasilitator" dan siswa sebagai "peserta aktif" dalam proses belajar mengajar. Karena itu, guru dituntut untuk menciptakan teknik mengajar yang baik, menyajikan bahan ajar yang menarik, sementara siswa dituntut untuk aktif berpartisipasi dalam proses belajar. Pembelajaran online juga sering disebut dengan pembelajaran daring atau "dalam jaringan (online)". Pemanfaatan sistem pembelajaran daring merupakan salah satu upaya yang bisa dilakukan untuk mengatasi permasalahan dan memudahkan siswa mengakses materi pembelajaran. Riyanda et al., (2020: 70) menjelaskan bahwa beberapa hal yang dapat dilakukan selama pembelajaran daring (daring) adalah saling berkomunikasi dan berdiskusi secara online.

Pemanfaatan sistem pembelajaran daring yaitu pemanfaatan jaringan internet merupakan salah satu upaya yang bisa dilakukan untuk mengatasi permasalahan dan memudahkan siswa mengakses materi pembelajaran. Dengan pembelajaran daring siswa memiliki keleluasaan waktu belajar, dapat belajar kapan pun dan dimana pun. Siswa dapat berinteraksi dengan guru menggunakan beberapa aplikasi seperti classroom, video conference, telepon atau live chat, zoom maupun melalui whatsapp group. Keberhasilan suatu model ataupun media pembelajaran tergantung dari karakteristik siswanya.Sebagaimana yang diungkapkan oleh Nakayama bahwa dari semua literatur dalam e-learning mengindikasikan bahwa tidak semua siswa akan sukses dalam pembelajaran online. Ini dikarenakan faktor lingkungan belajar dan karakteristik siswa (Nakayama et al., 2007: 1)

Seluruh sekolah di Indonesia termasuk SDIT Hidayatullah Kota Bengkulu yang mengalami dampak pandemi COVID-19 telah melaksanakan pembelajaran daring sejak awal merebaknya pandemi ini, tepatnya sejak tanggal 16 Maret 2020. Pembelajaran yang dilaksanakan di sekolah dasar juga menggunakan pembelajaran daring melalui bimbingan orang tua. Peran orang tua dalam pelaksanaan pembelajaran daring sangat menentukan. Mereka menjadi ujung tombak proses pembelajaran berjalan dengan baik. Guru memberikan instruksi dan dituntut menguasai ilmu teknologi agar pembelajaran efektif sedangkan orang tua membantu menjelaskan dan melaksanakan maksud dari instruksi kepada siswa. Oleh karena itu, orang tua dituntut maksimal dalam mendampingi putra dan putrinya saat belajar dari rumah.

Orang tua dengan latar pendidikan yang tinggi mungkin akan sangat mudah beradaptasi dalam proses pembelajaran secara daring. Namun, orang tua dengan latar belakang pendidikan yang minim mungkin jauh lebih sulit untuk beradaptasi dengan proses pembelajaran secara daring ini disebabkan minimnya pengetahuan akan teknologi. Selain itu, sebagian besar orang tua adalah pekerja yang tidak mempunyai waktu khusus untuk selalu mendampingi anaknya dalam kegiatan pembelajaran. Jaringan internet yang lemah juga menjadi salah satu faktor yang dapat menghambat proses pembelajaran daring. Hal tersebut karena proses pembelajaran daring dapat berjalan lancar jika kualitas jaringan internet lancar dan stabil. Proses pembelajaran secara daring ini juga membuat guru kesulitan dalam menyampaikan materi pembelajaran, dikarenakan tidak semua siswa berantusias 
dalam mengikuti proses pembelajaran secara daring. Belum lagi kendala teknis lainnya seperti pengadaan sarana pembelajaran daring baik di rumah maupun di sekolah yang belum merata. Hal-hal di atas adalah sebagian dari persoalan yang dibahas dalam pertemuan pengurus komite, kepala sekolah, dan yayasan pada tanggal 26 September 2020. Tindak lanjut dari pertemuan tersebut adalah dibuatnya edaran persetujuan pembelajaran dikombinasi daring dan tatap muka yang hasilnya 90\% setuju pembelajaran daring kombinasi tatap muka dan 10\% masih menginginkan pembelajaran daring.

Hasil penelitian yang berkaitan dengan pembelajaran daring di masa pandemi dilakukan oleh Yudiawan (2020). Hasilnya menunjukkan bahwa pembelajaran daring telah terlaksana dengan baik di tengah pandemi COVID-19 dan dapat digunakan sebagai media pembelajaran selama pandemi. Indikator Context, Input, Process dan rata-rata Product dalam kategori baik. Hanya saja dalam penelitian belum melibatkan orang tua sebagai responden yang memiliki peran tidak langsung dalam pelaksanaan pembelajaran daring.

Menyikapi hasil tersebut, dianggap perlu kiranya dilakukan evaluasi untuk mengetahui lebih dalam aspek-aspek apa saja yang mempengaruhi pelaksanaan pembelajaran daring selama pandemi COVID-19 di SDIT Hidayatullah. Penelitian ini menggunakan model evaluasi CIPP (Context, Input, Process, and Product) dengan metode deskriptif kuantitatif. Model evaluasi CIPP bertujuan membantu evaluator dalam mengevaluasi program, proyek, atau institusi. Model ini banyak digunakan untuk mengevaluasi program pendidikan yang berskala internasional, nasional, dan lokal. Oleh karena itu penelitian ini difokuskan untuk mengevaluasi pelaksanaan pembelajaran daring pada masa pandemi COVID-19 yang ditinjau dari Context, Input, Process, dan Product. Penelitian ini diharapkan dapat memberikan gambaran pelaksanaan pembelajaran daring di lingkungan SDIT Hidayatullah Kota Bengkulu.

\section{Metode}

Penelitian ini menggunakan model evaluasi CIPP (Context, Input, Process, and Product). Model ini dikembangkan oleh National Study Committe on Evaluation of Phi Delta Kappa. Penggagas model ini adalah Stuflebeam, yang mana model ini termasuk dalam model management analysis yang biasanya untuk mengevaluasi kebijakan manager. Dalam perkembangannya model ini digunakan untuk mengevaluasi program pendidikan (Mulyatiningsih, 2011: 117-118). Penelitian difokuskan untuk mengevaluasi pelaksanaan pembelajaran daring pada masa pandemi COVID-19 yang ditinjau dari Context, Input, Process, dan Product. Digunakan metode penelitian deskriptif kuantitatif.

Populasi 40 guru, 221 siswa kelas $4-6$, dan populasi 217 orang tua di lingkungan SDIT Hidayatullah Kota Bengkulu. Jumlah sampel ditetapkan melalui rumus Slovin (Juliansyah, 2011: 158) dengan margin error 10\% diperoleh sampel 29 guru, 69 siswa, dan 68 orang tua. Penentuan sampel dengan teknik clustered random sampling.

Teknik pengumpulan data dalam penelitian ini adalah angket dan dokumentasi. Menurut Mulyatiningsih (2011: 28) angket merupakan alat pengumpulan data yang memuat sejumlah pertanyaan atau pernyataan yang harus dijawab oleh subyek penelitian. Angket pada penelitian ini berupa angket tertutup berskala likert yang dilakukan secara daring melalui google form yang digunakan untuk mengumpulkan data. Selanjutnya data yang diperoleh dilakukan tabulasi untuk dianalisis secara deskriptif kuantitatif. Jenis data yang digunakan adalah data primer, artinya data yang langsung didapatkan dari subyek penelitian yaitu guru, siswa, dan orang tua. 
Menurut Arikunto (2004: 206), dokumentasi adalah mencari data mengenai hal-hal atau variabel yang berupa catatan, transkrip, buku, surat kabar, majalah, prasasti, notulen rapat, agenda, dan sebagainya. Dokumentasi digunakan untuk melengkapi data kuesioner atau angket. Dokumentasi yang dibutuhkan penulis berupa gambar atau foto kegiatan, data siswa, data guru, data orang tua, profil sekolah, agenda kegiatan pembelajaran, dokumen perangkat pembelajaran, laporan hasil belajar siswa, dan catatan lain yang berhubungan dengan penelitian.

Teknik analisis data menggunakan rerata (mean) dengan kriteria penilaian yang telah ditentukan dengan keterangan sangat baik, baik, kurang baik, dan sangat kurang baik.

\section{Hasil}

\section{Evaluasi Context}

Evaluasi yang diteliti pada aspek Context meliputi dua variabel yaitu tujuan pembelajaran dan kebutuhan pembelajaran. Berdasarkan analisis data angket responden guru dengan bantuan software Microsoft Excel 2013, hasil yang diperoleh dari aspek Context memiliki kecenderungan kategori sangat baik pada kedua variabel.

Hasil analisis menunjukkan rerata tujuan pembelajaran daring diperoleh nilai sebesar 4,39 dengan kategori sangat baik dan kebutuhan pembelajaran daring diperoleh nilai sebesar 4,37 dengan kategori sangat baik. Hal ini juga didukung dengan penelusuran dokumen yang diperoleh penulis tentang tujuan pembelajaran yang tertuang dalam perangkat ajar yang dibuat oleh guru untuk kegiatan pembelajaran daring dan kebutuhan pembelajaran yang terekam dalam dokumen kegiatan pembelajaran melalui aplikasi whatsapp maupun youtube.

\section{Evaluasi Input}

Evaluasi yang diteliti dalam aspek Input meliputi kompetensi guru, keterlibatan siswa, sarana prasarana, perangkat pembelajaran, dan peran orang tua dalam pembelajaran daring. Data angket dianalisis dan dikelompokkan berdasarkan masing-masing responden yaitu guru, siswa, dan orang tua.

\section{a. Aspek Input dengan Responden Guru}

Berdasarkan analisis data angket responden guru dengan bantuan software Microsoft Excel 2013, hasil analisis rerata yang diperoleh dari aspek Input memiliki kategori baik. Hasil analisis rerata lima variabel pada aspek Input yaitu: Pertama, variabel kompetensi guru yang terlibat dalam pembelajaran daring diperoleh rerata nilai sebesar 4,24. Kedua, variabel keterlibatan siswa dalam pembelajaran daring diperoleh rerata nilai sebesar 4,11. Ketiga, variabel sarana prasarana yang menunjang pelaksanaan pembelajaran daring diperoleh rerata nilai sebesar 4,15. Keempat, variabel perangkat pembelajaran daring diperoleh rerata nilai sebesar 4,17. Kelima, variabel peran orang tua dalam pembelajaran daring diperoleh rerata nilai sebesar 4,20 .

Hal ini juga ditunjukkan dalam penelusuran dokumentasi yaitu adanya screenshot percakapan di grup whatsapp dan dokumen perangkat ajar yang dimiliki oleh guru. Ketersediaan sarana dan prasarana pun sudah lengkap untuk kegiatan pembelajaran daring seperti guru memiliki laptop atau handphone yang memadai, wifi dan listrik yang memadai. Sekolah juga memiliki kanal youtube yang dapat diakses oleh guru, siswa, dan orang tua. Kanal youtube yang dibuat oleh sekolah ada dua yaitu untuk pelajaran umum dan diniyah. Tampilan muka (interface) dari situs pelajaran umum https://youtube.com/channel/UCDx1AKfSJ yzLNiKuCWoOM0g dan 
situs pelajaran diniyah https://youtube. com/channel /UCPPuI d5WN 2lmbCAlR8 1h0VA.

\section{b. Aspek Input dengan Responden Siswa}

Berdasarkan analisis data angket responden siswa dengan bantuan software Microsoft Excel 2013, hasil yang diperoleh dari aspek Input memiliki kategori baik hingga sangat baik pada ketiga variabel. Hasil analisis rerata tiga variabel pada aspek Input yaitu: pertama, variabel keterlibatan siswa dalam pembelajaran daring diperoleh rerata nilai sebesar 4,08 dengan kategori baik. Kedua, variabel sarana prasarana yang menunjang pelaksanaan pembelajaran daring diperoleh rerata nilai sebesar 4,14 dengan kategori baik. Ketiga, variabel peran orang tua dalam pembelajaran daring diperoleh rerata nilai sebesar 4,25 dengan kategori sangat baik.

\section{c. Aspek Input dengan Responden Orang Tua}

Berdasarkan analisis data angket responden orang tua dengan bantuan software Microsoft Excel 2013, hasil yang diperoleh dari aspek Input memiliki kategori baik pada ketiga variabel. Hasil analisis rerata tiga variabel pada aspek Input. Pertama, variabel keterlibatan siswa dalam pembelajaran daring diperoleh rerata nilai sebesar 3,76 dengan kategori baik. Kedua, variabel sarana prasarana yang menunjang pelaksanaan pembelajaran daring diperoleh rerata nilai sebesar 3,81 dengan kategori baik. Ketiga, variabel peran orang tua dalam pembelajaran daring diperoleh rerata nilai sebesar 4,06 dengan kategori baik.

\section{Evaluasi Process}

Evaluasi yang diteliti dalam aspek Process meliputi pelaksanaan pembelajaran, aktivitas siswa, dan hambatan/kendala dalam pembelajaran daring. Data angket dianalisis dan dikelompokkan berdasarkan masing-masing responden yaitu guru, siswa, dan orang tua.

\section{a. Aspek Process dengan Responden Guru}

Berdasarkan analisis data angket responden guru dengan bantuan software Microsoft Excel 2013, hasil yang diperoleh dari aspek Process memiliki kategori kurang baik hingga baik pada ketiga variabel. Hasil hitung rerata tiga variabel pada aspek Process. Pertama, variabel pelaksanaan pembelajaran daring diperoleh rerata nilai sebesar 4,04 dengan kategori baik. Kedua, variabel aktivitas siswa diperoleh rerata nilai 3,96 dengan kategori baik. Ketiga, variabel hambatan/kendala dalam pembelajaran daring diperoleh rerata nilai 2,48 dengan kategori kurang baik.

\section{b. Aspek Process dengan Responden Siswa}

Berdasarkan analisis data angket responden siswa dengan bantuan software Microsoft Excel 2013, hasil yang diperoleh dari aspek Process memiliki kecenderungan kategori cukup baik hingga baik pada ketiga variabel. Hasil analisis rerata tiga variabel pada aspek Process. Pertama, variabel pelaksanaan pembelajaran daring diperoleh rerata nilai 4,00 dengan kategori baik. Kedua, variabel aktivitas siswa diperoleh rerata nilai sebesar 3,92 dengan kategori baik. Ketiga, variabel hambatan/kendala dalam pembelajaran daring diperoleh rerata nilai sebesar 2,80 dengan kategori cukup baik.

\section{c. Aspek Process dengan Responden Orang Tua}

Berdasarkan analisis data angket responden orang tua dengan bantuan software Microsoft Excel 2013, hasil yang diperoleh dari aspek Process memiliki kecenderungan kategori kurang baik hingga baik pada ketiga variabel. Hasil analisis rerata tiga variabel pada aspek Process. Pertama, variabel pelaksanaan pembelajaran daring diperoleh rerata nilai 3,61 dengan kategori baik. Kedua, variabel aktivitas siswa diperoleh rerata nilai sebesar 3,74 dengan kategori baik. 
Ketiga, variabel hambatan/kendala dalam pembelajaran daring diperoleh rerata nilai sebesar 2,34 dengan kategori kurang baik.

\section{Evaluasi Product}

Evaluasi Product pada penelitian ini meliputi hasil belajar siswa dan dampak pembelajaran bagi siswa. Data angket dianalisis dan dikelompokkan berdasarkan masing-masing responden yaitu guru, siswa, dan orang tua.

\section{a. Aspek Product dengan Responden Guru}

Berdasarkan analisis data angket responden guru dengan bantuan software Microsoft Excel 2013, hasil yang diperoleh dari aspek Product memiliki kecenderungan kategori cukup baik pada kedua variabel. Hasil analisis rerata dua variabel pada aspek Product. Pertama, variabel hasil belajar siswa diperoleh rerata nilai sebesar 3,29 dengan kategori cukup baik. Kedua, variabel dampak pembelajaran bagi siswa diperoleh rerata nilai sebesar 3,26 dengan kategori cukup baik. Kesimpulan yang dapat diambil dengan melihat kecenderungan kedua variabel adalah pelaksanaan pembelajaran daring pada masa pandemi COVID-19 di SDIT Hidayatullah Kota Bengkulu ditinjau dari aspek Product termasuk dalam kategori cukup baik.

\section{b. Aspek Product dengan Responden Siswa}

Berdasarkan analisis data angket responden siswa dengan bantuan software Microsoft Excel 2013, hasil yang diperoleh dari aspek Product memiliki kecenderungan kategori cukup baik pada kedua variabel. Hasil analisis rerata dua variabel pada aspek Product. Pertama, variabel hasil belajar siswa diperoleh rerata nilai sebesar 3,27 dengan kategori cukup baik. Kedua, variabel dampak pembelajaran bagi siswa diperoleh rerata nilai sebesar 3,39 dengan kategori cukup baik.

\section{c. Aspek Product dengan Responden Orang Tua}

Berdasarkan analisis data angket responden orang tua dengan bantuan software Microsoft Excel 2013, hasil yang diperoleh dari aspek Product memiliki kecenderungan kategori baik pada kedua variabel. Hasil analisis rerata dua variabel pada aspek Product. Pertama, variabel hasil belajar siswa diperoleh rerata nilai sebesar 2,59 dengan kategori kurang baik. Kedua, variabel dampak pembelajaran bagi siswa diperoleh rerata nilai sebesar 2,88 dengan kategori cukup baik.

Berdasarkan rekapitulasi hasil analisis dengan tiga responden, maka dapat disimpulkan rata-rata dari aspek Context, Input, Process, dan Product. Pertama, aspek Context diperoleh rerata nilai sebesar 4,38 dengan kategori sangat baik. Kedua, aspek Input diperoleh rerata sebesar 4,13 dengan kategori baik. Ketiga, aspek Process diperoleh rerata nilai sebesar 3,43 dengan kategori baik. Keempat, aspek Product diperoleh rerata nilai sebesar 3,11 dengan kategori cukup baik.

\section{Pembahasan}

\section{Evaluasi Context}

Penelitian yang telah dilakukan pada 29 responden guru diperoleh data mengenai variabel tujuan pembelajaran dan kebutuhan pembelajaran daring. Dalam variabel tujuan pembelajaran daring, rerata nilai yang diperoleh adalah 4,39 yang termasuk dalam kategori sangat baik yang artinya pembelajaran daring terlaksana dengan sangat baik. Jadi, hasil data ini menunjukkan bahwa tujuan pembelajaran daring sangat sesuai dalam pemberian layanan dan rumusan pembelajaran pada masa pandemi COVID-19. Hal ini tertuang dalam surat edaran Kemdikbud yaitu memastikan pemenuhan hak siswa untuk mendapatkan layanan pendidikan selama darurat COVID-19, melindungi warga satuan pendidikan dari dampak buruk 
COVID-19, mencegah penyebaran dan penularan COVID-19 di satuan pendidikan dan memastikan pemenuhan dukungan psikososial bagi guru, siswa, dan orang tua (Kemdikbud, 2020b).

Berdasarkan analisis data variabel kebutuhan pembelajaran daring, rerata nilai yang diperoleh adalah 4,37 yang termasuk dalam kategori sangat baik artinya pembelajaran daring terlaksana dengan sangat baik. Jadi, hasil data ini menunjukkan bahwa kebutuhan pembelajaran daring telah sesuai dengan tujuan pembelajaran yaitu memberikan layanan pembelajaran bermutu dalam jaringan (daring) yang bersifat masif dan terbuka untuk menjangkau audiens yang lebih banyak dan lebih luas (Hanum, 2013: 98). Kebutuhan pembelajaran sejalan dengan kondisi Indonesia yang berada pada masa pandemi COVID-19 yaitu kebutuhan sosial dan normatif. Kebutuhan sosial merupakan kebutuhan yang umum dalam pendidikan yang sejalan dengan tujuan pembelajaran sedangkan kebutuhan normatif adalah kebutuhan yang timbul apabila seseorang atau suatu kelompok berada dalam keadaan di bawah suatu ukuran (standard) yang telah ditetapkan (Briggs, 1977: 22).

\section{Evaluasi Input}

Hasil penelitian meliputi lima variabel yaitu: kompetensi guru, keterlibatan siswa, sarana prasarana, perangkat pembelajaran, dan peran orang tua dalam pembelajaran daring. Data diperoleh dari tiga responden yang merupakan sampel penelitian yaitu 29 guru, 69 siswa, dan 68 orang tua. Hasil analisis dengan reponden guru pada variabel kompetensi guru diperoleh rerata nilai sebesar 4,24 yang termasuk dalam kategori sangat baik yang artinya pembelajaran daring terlaksana dengan sangat baik. Jadi, hasil data menunjukkan bahwa guru yang melaksanakan pembelajaran daring memiliki kompetensi yang sangat baik karena mampu mengembangkan kelas tradisional menjadi kelas digital. Selain itu, hasil data juga menunjukkan bahwa guru telah mampu mengelola waktu pembelajaran yang durasinya panjang dari pagi hingga malam hari dan terampil dalam penilaian dan evaluasi secara digital. Seorang guru harus memiliki empat keterampilan dalam melaksanakan pembelajaran daring. Menurut Bahar (2020: 1) empat keterampilan yang harus dimiliki guru dalam sistem pembelajaran jarak jauh (distance learning) yaitu: keterampilan komunikasi digital, pengelolaan waktu, keterampilan penilaian dan evaluasi, dan keterampilan mengembangkan kurikulum. Keempat keterampilan tersebut menjadi prasyarat seorang guru berkompeten dalam melaksanakan pembelajaran daring.

Berdasarkan analisis data variabel keterlibatan siswa dengan responden guru diperoleh rerata nilai sebesar 4,11, dengan responden siswa diperoleh rerata nilai sebesar 4,08, dan responden orang tua diperoleh rerata nilai sebesar 3,76. Ketiga responden menunjukkan kecenderungan hasil yang baik artinya pembelajaran daring terlaksana dengan baik. Ini membuktikan bahwa siswa terlibat aktif baik secara perilaku, kognitif, dan emosi. Hal tersebut sesuai dengan pendapat Fredricks, et.al., (2004) bahwa keterlibatan siswa memiliki tiga aspek yaitu terlibat secara perilaku, kognitif, dan emosi. Keterlibatan perilaku meliputi siswa mengikuti aturan sekolah dan aturan pembelajaran. Keterlibatan kognitif meliputi penguasaan pembelajaran, menyelesaikan tugas-tugas yang diberikan, dan memiliki tujuan dan keinginan untuk belajar. Keterlibatan emosi meliputi sikap positif terhadap sekolah dan pembelajaran.

Rerata nilai hasil hitung keterlibatan siswa dengan responden orang tua lebih kecil dibandingkan responden guru dan siswa meskipun masih dalam kategori baik. Ada beberapa faktor yang menyebabkan hal tersebut terjadi diantaranya: 1) Tujuan dan keinginan belajar siswa bergantung dari motivasi orang tua. Hal ini sesuai dengan pendapat bahwa Dalyono (2005: 57) yang menyatakan bahwa orang tua selain 
memiliki peran sebagai pendidik juga sebagai motivator yaitu menumbuhkan motivasi atau rangsangan dari luar yang kemudian mampu secara alamiah menumbuhkan motivasi dari dalam diri anak tersebut. 2) Perbedaan tingkat pemahaman materi pelajaran pada setiap siswa tidak sama. Hal ini sesuai hasil penelitian dari Apriliana et al. (2020: 30) yang menyatakan bahwa tingkat pemahaman siswa berbeda-beda karena siswa sekolah dasar sulit menangkap materi yang abstrak dan penyampaian secara daring dalam waktu terus menerus menyebabkan siswa kesulitan memahami materi. 3) Kurangnya pemahaman materi oleh orang tua sehingga orang tua kesulitan mendampingi anaknya. Sejalan dengan penelitian sebelumnya yang menyatakan bahwa selama pembelajaran di rumah atau daring, banyak orang tua yang kurang dalam memahami materi yang diberikan oleh sekolah atau pihak guru sehingga mereka sulit menyampaikan kepada anaknya (Cahyati, 2020: 775).

Berdasarkan analisis data variabel sarana prasarana dengan responden guru, diperoleh rerata nilai sebesar 4,15, dengan responden siswa diperoleh rerata nilai sebesar 4,14, dan responden orang tua diperoleh rerata nilai sebesar 3,81. Ketiga responden menunjukkan kecenderungan hasil yang baik dan ini membuktikan bahwa sarana prasarana yang menunjang pembelajaran daring telah lengkap. Sarana prasarana yang tersedia di sekolah dan yang disediakan oleh orang tua cukup memadai untuk dilaksanakannya pembelajaran daring. Sekolah memiliki fasilitas listrik, wifi, dan platform atau aplikasi yang mudah diakses oleh siswa dan orang tua. Guru, siswa, dan orang tua juga memilki smartphone atau laptop yang memadai dalam pembelajaran daring. Hal ini dinyatakan oleh Gikas \& Grant (2013: 22), bahwa pembelajaran daring membutuhkan adanya fasilitas sebagai penunjang seperti smartphone, laptop atau pun tablet. Martins (2015: 80) juga menyebutkan internet telah dipadukan menjadi sebuah alat yang digunakan untuk melengkapi aktivitas pembelajaran.

Rerata hasil analisis sarana prasarana dengan responden orang tua nilainya lebih kecil dibandingkan responden guru dan siswa meskipun masih dalam kategori baik. Hal tersebut dapat disebabkan sebagian orang tua memiliki keterbatasan dalam mengakses internet karena trafic jaringan atau koneksi internet yang lemah dan terbatasnya kuota internet. Hal ini sependapat dengan pernyataan Yulianti (2020: 779) bahwa kepulauan Indonesia yang beragam menyebabkan tidak semua wilayah terjangkau oleh layanan internet yang lambat sewaktu-waktu. Menurut Jones \& Sharma (2019: 779) penggunaan jaringan internet membutuhkan biaya yang tidak sedikit.

Berdasarkan hasil analisis variabel perangkat pembelajaran pada 29 responden guru, diperoleh rerata nilai sebesar 4,17 dengan kategori baik yang artinya pembelajaran daring terlaksana dengan baik. Jadi, hasil data ini menunjukkan bahwa perangkat pembelajaran daring lengkap dan sesuai untuk pelaksanaan pembelajaran daring. Perangkat pembelajaran meliputi silabus, RPP, dan bahan ajar berbasis web disiapkan dengan baik oleh setiap guru sebelum melaksanakan pembelajaran daring. Hal ini dilakukan karena dalam pembelajaran daring perangkat yang harus dikembangkan adalah silabus, RPP, dan bahan ajar berbasis web (Kemdikbud, 2020). Rencana Pelaksanaan Pembelajaran (RPP) yang dibuat guru juga sesuai dengan anjuran pemerintah yaitu RPP satu lembar. Penyederhanaan RPP sesuai dengan Permendikbud nomor 14 tahun 2019 tertanggal 13 Desember 2019 merupakan salah satu terobosan baru yang dilakukan oleh Menteri Pendidikan dan Kebudayaan Nadiem Makarim, ia menyebutkan penyederhanaan RPP ini didedikasikan untuk para guru agar meringankan beban administrasi guru, ia juga menambahkan selanjutnya Kemendikbud akan memberikan beberapa contoh RPP singkat yang cukup dikerjakan dalam satu halaman (Kemdikbud, 2019). 
Berdasarkan analisis data variabel peran orang tua dengan responden guru, diperoleh rerata nilai sebesar 4,20, dengan responden siswa diperoleh rerata nilai sebesar 4,25, dan dengan responden orang tua diperoleh persentase sebesar 4,06. Kedua responden yaitu guru dan siswa menunjukkan kecenderungan hasil yang sangat baik dan responden orang tua menunjukkan hasil yang baik. Ini membuktikan bahwa peran orang tua dalam pembelajaran daring tingkat keterlaksanaannya baik hingga sangat baik. Peranan orang tua sangat penting dalam mendampingi anak-anaknya, terutama dalam pembelajaran daring. Hal ini karena pendampingan yang dilakukan oleh orang tua dalam melakukan kegiatan belajar di rumah akan berpengaruh terhadap tingkah laku yang mengarah pada kedisiplinan dalam belajar. Menurut Cahyati (2020: 155), terdapat empat peran orang tua dalam pembelajaran daring yaitu sebagai guru di rumah, fasilitator, motivator, dan direktur. berjalan dengan baik. Keempat peran tersebut dapat dijalankan dengan baik oleh orang tua.

\section{Evaluasi Process}

Hasil penelitian dalam evaluasi Process meliputi tiga variabel yaitu: pelaksanaan pembelajaran, aktivitas siswa, dan hambatan/kendala dalam pembelajaran daring. Data diperoleh dari tiga responden yang merupakan sampel penelitian yaitu 29 guru, 69 siswa, dan 68 orang tua. Hasil analisis variabel pelaksanaan pembelajaran daring dengan responden guru diperoleh rerata nilai sebesar 4,04, dengan responden siswa diperoleh rerata nilai sebesar 4,00, dan dengan responden orang tua diperoleh rerata nilai sebesar 3,61. Ketiga responden menunjukkan kecenderungan hasil yang baik. Ini artinya bahwa pelaksanaan pembelajaran daring terlaksana dengan baik. Jadi, hasil data menunjukkan bahwa media yang digunakan dalam proses pembelajaran dimanfaatkan dengan baik oleh guru, siswa, dan orang tua. Selain whatsapp dan youtube, hanya sedikit siswa yang menggunakan media lain untuk mengakses pembelajaran. Sependapat dengan hal tersebut bahwa whatsapp adalah salah satu media yang familier belakangan ini. whatsapp banyak digunakan di tingkat sekolah dasar. Berdasarkan survei yang dilakukan, 100\% pembelajaran daring di SD menggunakan Whatsapp Grup (Daheri et al., 2020: 775). Guru umumnya memberikan pembelajaran lebih banyak dengan membuat video yang diunggah ke youtube agar siswa mudah mengaksesnya dengan mengirimkan link nya ke grup whatsapp. Setelah siswa selesai menonton, guru memberikan soal atau membuat grup diskusi untuk memecahkan suatu masalah. Metode pembelajaran daring ini efektif untuk menciptakan ruang interaktif baru bagi pendidik dan siswa.

Rerata hasil analisis pelaksanaan pembelajaran dengan responden orang tua nilainya lebih kecil dibandingkan responden guru dan siswa meskipun masih dalam kategori yang sama yaitu kategori baik. Hal ini disebabkan siswa lebih banyak menggunakan atau mengakses pembelajaran via whatsapp dan youtube saja. Whatsapp memiliki beberapa fitur yang mudah digunakan seperti fasilitas obrolan grup, pengirim dokumen, video, gambar, panggilan suara maupun panggilan video. Sesuai dengan Prajana (2007: 125) konten whatsapp yang bisa digunakan meliputi chat group untuk integrasi antara guru dan siswa atau orang tua. Fasilitas share document digunakan untuk membantu kelompok belajar mengirim dokumen dalam bentuk file, camera digunakan untuk membagi beberapa kegiatan yang membutuhkan gambar yang diambil pada sebuah kegiatan, dan audio digunakan untuk membagikan file berupa suara.

Berdasarkan analisis data variabel aktivitas siswa dengan responden guru diperoleh rerata nilai sebesar 3,96, dengan responden siswa diperoleh rerata nilai sebesar 3,92, dan dengan responden orang tua diperoleh rerata nilai sebesar 3,74. Ketiga responden menunjukkan kecenderungan hasil yang baik. Ini berarti bahwa aktivitas siswa dalam pembelajaran daring terlaksana dengan baik. Aktivitas belajar siswa merupakan kegiatan atau tindakan baik fisik maupun mental yang dilakukan untuk 
membangun pengetahuan dan keterampilan diri dalam kegiatan pembelajaran. Menurut Hamalik (2004: 179) menyatakan bahwa aktivitas belajar merupakan kegiatan yang dilakukan oleh siswa dalam kegiatan pembelajaran. Kegiatan tersebut meliputi kegiatan visual, lisan, mendengarkan, menulis, motorik, mental, dan emosional.

Berdasarkan hasil analisis sub variabel aktivitas mendengarkan dengan tiga responden menunjukkan rerata yang kecil dibandingkan sub variabel lainnya. Hal ini karena rerata nilai pada sub variabel aktivitas mendengar hanya sebesar 3,63 dan aktivitas emosional sebesar 3,16. Ini dapat disebabkan karena aktivitas mendengarkan percakapan, diskusi, atau pidato dalam pembelajaran daring jarang dilakukan dan interaksi yang minim menyebabkan siswa kurang bersemangat. Siswa lebih banyak belajar mandiri dengan membaca, mendengarkan tutorial atau video pembelajaran, atau tanya jawab secara tertulis yang dilakukan dengan chat group. Hal ini sesuai dengan pendapat Sari (2015: 28) bahwa pembelajaran daring adalah pembelajaran jarak jauh yang membuat guru dan siswa atau siswa dengan siswa terpisah secara fisik dan mengakibatkan tidak adanya interaksi secara langsung sehingga siswa dituntut belajar mandiri. Keadaan ini juga menyebabkan siswa tidak bersemangat dan gembira dengan pembelajaran daring karena interaksi yang kurang antara siswa dengan guru dan siswa dengan siswa lainnya.

Berdasarkan analisis data variabel hambatan/kendala dengan responden guru diperoleh rerata nilai sebesar 2,48 , dengan responden siswa diperoleh rerata nilai sebesar 2,80, dan dengan responden orang tua diperoleh rerata nilai sebesar 2,34. Ketiga responden memberikan kecenderungan hasil yang berbeda. Hasil analisis dengan responden guru dan orang tua menunjukkan hasil yang kurang baik sedangkan dengan responden siswa menunjukkan hasil yang cukup baik. Hal ini membuktikan bahwa terdapat hambatan/kendala yang dihadapi oleh guru maupun orang tua dalam pembelajaran daring dan hambatan/kendala tersebut lebih dirasakan oleh siswa. Hambatan atau kendala yang sering dihadapi dalam pembelajaran daring antara lain: jaringan internet yang tidak stabil, kuota yang terbatas, merasa cepat bosan, belum memiliki inisiatif belajar mandiri, sulit fokus, lebih senang belajar tatap muka, tugas terlalu banyak atau sulit membagi waktu. Hambatan/kendala tersebut diklasifikasikan dalam 3 kendala yaitu kendala teknis, kendala interaksi, dan kendala pendukung (Utami dan Cahyono, 2020: 21). Berdasarkan hasil analisis sub variabel pada masing-masing responden, hambatan/kendala yang paling banyak dihadapi adalah kendala interaksi yaitu belum memiliki inisiatif belajar mandiri dan sulit fokus sedangkan kendala tenis diantaranya jaringan internet yang tidak stabil dan terbatasnya kuota internet lebih kecil. Hambatan/kendala ini telah diminimalisir oleh sekolah maupun pemerintah yaitu dengan tersedianya jatah kuota belajar 35 GB dari pemerintah yang didata melalui data dapodik, ada jatah pulsa sebesar Rp. 25.000,-/per bulan dari sekolah, tugas di sekolah lebih sedikit dengan memberikan pembelajaran 2 kali dalam satu pekan dan jika ada tugas dapat dikumpulkan sampai jam 21.00 setiap harinya.

\section{Evaluasi Product}

Hasil penelitian meliputi dua variabel yaitu: hasil belajar dan dampak pembelajaran. Data diperoleh dari tiga responden yang merupakan sampel penelitian yaitu 29 guru, 69 siswa, dan 68 orang tua. Hasil analisis pada variabel hasil belajar dengan reponden guru diperoleh rerata nilai sebesar 3,29, dengan responden siswa diperoleh rerata nilai sebesar 3,27 , dan dengan responden orang tua diperoleh rerata nilai sebesar 2,59. Ketiga responden memberikan kecenderungan hasil yang berbeda. Hasil analisis dengan responden guru dan siswa cukup baik sedangkan dengan responden orang tua menunjukkan hasil kurang baik. Berdasarkan hasil analisis sub variabel dengan responden guru diketahui bahwa penilaian kognitif atau kompetensi pengetahuan lebih tinggi hasil rerata nilainya dibandingkan afektif dan 
psikomotorik. Hal ini juga dibuktikan dari tabel rata-rata nilai semester satu yang menunjukkan nilai yang lebih tinggi pada kompetensi pengetahuan. Sedangkan dengan responden orang tua dan siswa, hasil rerata lebih tinggi pada penilaian afektif dibandingkan kognitif dan psikomotorik. Meskipun tabel menunjukkan ratarata nilai yang tinggi pada kompetensi pengetahuan atau kognitif tetapi secara individu terdapat siswa yang mengalami penurunan nilai sehingga hasil data responden berbeda-beda. Perbedaan hasil belajar siswa bergantung pada beberapa faktor. Menurut Sugiharto, et.al. (2007: 76-77) faktor-faktor yang mempengaruhi hasil belajar antara lain: faktor internal (faktor yang ada dalam diri individu, jasmani maupun psikologis) dan faktor eksternal (faktor dari luar, meliputi keluarga, sekolah atau masyarakat).

Rerata hasil analisis hasil belajar dengan responden orang tua termasuk dalam kategori kurang baik. Hal ini disebabkan karena sub variabel kognitif dan psikomotorik menunjukkan rerata yang rendah sehingga mempengaruhi keseluruhan rerata hasil belajar siswa. Hal ini bisa terjadi karena evaluasi pencapaian hasil belajar yang diukur pada variabel kognitif hanya didasarkan pada tes obyektif siswa dan variabel psikomotorik didasarkan pada saat pembelajaran praktik berlangsung. Tes obyektif memiliki kelemahan yaitu jika salah maka bernilai nol, dan siswa tidak bebas menjawab karena siswa tidak dapat mengorganisasikan, menghubungkan, dan menyatakan idenya sendiri karena semua alternatif jawaban sudah diberikan oleh guru (Weldan, 2019: 4) sedangkan pengambilan nilai psikomotorik hanya didasarkan pada video hasil praktik yang dikirim siswa, bukan penilaian secara langsung di kelas atau penilaian luring, sehingga penilaian proses ditiadakan. Menurut Juniarti (2018: 6), menurunnya hasil belajar siswa tersebut juga disebabkan beberapa faktor. Baik internal yaitu faktor yang berasal dari dalam diri siswa itu sendiri maupun faktor eksternal yaitu faktor yang berasal dari luar diri siswa (lingkungan siswa itu sendiri). Faktor yang berasal dari diri siswa antara lain: sikap malas, waktu, menggampangkan tugas, cara belajar siswa di rumah, terlalu santai. Adapun faktor dari luar diri siswa antara lain: lingkungan keluarga atau orang tua, lingkungan sekolah, dan lingkungan masyarakat. Selain itu, faktor lain juga yang menyebabkan dianggap menurunnya hasil belajar siswa adalah orang tua membandingkan hasil belajar di semester sebelumnya yang tatap muka atau luring dengan semester berjalan yang menggunakan metode daring.

Berdasarkan analisis data variabel dampak pembelajaran dengan responden guru diperoleh rerata nilai sebesar 3,26, dengan responden siswa diperoleh rerata nilai sebesar 3,39, dengan responden orang tua diperoleh rerata nilai sebesar 2,88. Ketiga responden memberikan kecenderungan hasil yang cukup baik. Ini berarti pembelajaran daring terlaksana dengan cukup baik. Hasil analisis sub variabel dampak positif pada ketiga responden menunjukkan hasil rerata yang baik yaitu sebesar 4,06 pada responden guru, rerata nilai sebesar 3,78 pada responden siswa, dan hasil rerata yang cukup baik pada orang tua yaitu sebesar 3,36. Hasil analisis sub variabel dampak negatif menunjukkan hasil rerata yang kurang baik yaitu sebesar 2,05 dengan responden guru dan 2,15 dengan responden orang tua. Sebaliknya dengan responden siswa, rerata yang diperoleh sebesar 2,81 yang termasuk kategori cukup baik. Hasil analisis tersebut membuktikan bahwa dampak pembelajaran daring yang dihadapi lebih tinggi dampak yang positif. Mudahnya mengakses pelajaran dari mana saja dan kapan saja, belajar materi lebih santai, serta mendapatkan rasa aman dan bebas dari COVID-19 adalah dampak positif yang dirasakan oleh guru maupun siswa (Heryan, 2020: 1). Sedangkan data responden orang tua menunjukkan hasil cukup baik, artinya orang tua mengetahui lebih 
banyak kondisi anak di rumah. Dampak positif diperoleh tentu dengan peran serta orang tua yang maksimal dalam pendampingannya sehingga keberhasilan anak adalah keberhasilan orang tua. Meskipun demikian, dalam pembelajaran daring, dampak negatif pun dirasakan terutama oleh siswa yaitu pembelajaran kurang efektif karena materi kurang dimengerti serta kurangnya penjelasan guru dan tugas yang menumpuk sehingga guru dan orang tua harus bekerja keras memastikan pembelajaran dari rumah berjalan dengan baik. Hal ini dapat diminimalisir dengan upaya orang tua mendampingi anak secara maksimal seperti yang disampaikan oleh Kurniati, et.al (2020: 148) upaya pendampingan yang dapat dilakukan orang tua di antaranya membantu ketika anak kesulitan, membimbing dan bahkan memberikan eksplorasi pembelajaran lebih mendalam terkait tugas yang diberikan.

Kesimpulan yang dapat diambil berdasarkan pembahasan di atas adalah bahwa pelaksanaan pembelajaran daring pada masa pandemi COVID-19 ditinjau dari aspek Context, Input, Process, dan Product rata-rata baik. Hal ini sesuai dengan penelitian dari Riyanda et al., (2020) yang menyimpulkan bahwa tingkat pencapaian program pada sistem pembelajaran daring komponen Conteks, Input, Process, dan Product rata-rata kategori baik.

\section{Simpulan}

Berdasarkan penelitian yang telah dilaksanakan, dapat disimpulkan bahwa:

1. Ditinjau dari aspek Context yang meliputi tujuan pembelajaran dan kebutuhan pembelajaran pada pelaksanaan pembelajaran daring pada masa pandemi COVID-19 terlaksana dengan sangat baik.

2. Ditinjau dari aspek Input yang mencakup kompetensi guru, keterlibatan siswa, sarana prasarana, perangkat pembelajaran, dan peran orang tua dalam pembelajaran daring pada masa pandemi COVID-19 terlaksana dengan baik.

3. Ditinjau dari Process yang mencakup pelaksanaan pembelajaran, aktivitas siswa, dan hambatan/kendala dalam pembelajaran daring pada masa pandemi COVID19 terlaksana dengan baik

4. Ditinjau dari Product yang mencakup hasil belajar dan dampak pembelajaran daring pada masa pandemi COVID-19 terlaksana cukup baik.

5. Ditinjau dari seluruh aspek CIPP, pelaksanaan pembelajaran daring pada masa pandemi terlaksana dengan baik.

\section{Saran}

Berdasarkan simpulan hasil penelitian dapat diberikan saran sebagai berikut.

1. Bagi peneliti lain

a) Dalam penelitian selanjutnya, disarankan untuk mengambil sampel yang lebih banyak, hal ini bertujuan untuk keakuratan data yang lebih baik dalam penelitiannya.

b) Melakukan penelitian yang berkelanjutan, hal ini agar dapat melihat dan menilai setiap perubahan perilaku responden dari waktu ke waktu

c) Diharapkan adanya tambahan variabel lain yang mungkin juga mempengaruhi banyak hal dalam penelitian ini.

2. Bagi kepala sekolah atau kepala lembaga pendidikan formal

a) Diharapkan sekolah dapat melaksanakan pembelajaran secara daring atau blended learning untuk menyongsong era digital yang semakin maju.

b) Kualitas pelayanan merupakan hal yang penting dalam pelaksanaan pembelajaran berbasis informasi dan teknologi, diharapkan sekolah dapat menjalin kerja sama yang intensif dengan lembaga lain yang mampu 
menyiapkan perangkat software dan hardware yang lebih mumpuni dalam c) memudahkan siswa belajar daring atau blended learning.

\section{Referensi}

Anonim. (2020). Update Virus Corona di Dunia 13 September 202028 Juta Orang Positif Corona. Https://www.pikiran-rakyat.com/internasional/pr01738545/update-virus-corona-di-dunia-13-September-2020-kasus-positifcovod-19-dekati-angka-29-juta-orang-positif-covid-19. Diakses 13 September 2020.

Apriliana, I.P.A., Suranata, K., \& Dharsana, I. K. (2020). Mereduksi Kecemasan Siswa Melalui KonselingCognitive Behavioral. Indonesian Journal of Educatinaol Conseling, 3(1), 21-30.

Arikunto, S. (2004). Dasar-dasar Evaluasi Pendidikan. Jakarta: Bumi Aksara.

Arsyad, A. (2011). Media pembelajaran. Jakarta: Rajawali Press.

Bahar, A. (2020). Empat Keterampilan yang Harus Dimiliki Guru dalam Sistem Pembelajaran Jarak Jauh (Distance Learning). https://www.ahzaa.net/2020/06/4-empat-keterampilan-yang-harus.html Diakses 10 Januari 2021.

Briggs, Leslie J. (1977). Instructional Design, Educational Technology Publication In. New Jersey: EnggleWoods Clifts.

Cahyati, N. (2020). Peran Orang Tua Dalam Menerapkan Pembelajaran di Rumah Saat Pandemi Covid 19. Jurnal Golden Age, 4(1).

Daheri, M., Juliana, D., \& Amda, A.,D. (2020). Efektifitas Whatsapp sebagai Media Belajar Daring. Jurnal Basicedu, 4(4), 775-783.

Dalyono, (2005). Psikologi Pendidikan. Jakarta: PT. Rineka Cipta.

Frederiks, J.A., Blumenfeld, P.C., \& Paris A. (2004). School Engagement: Potential of The Concept, State of Evidence. Review of Educational Research, New York: Springer.

Gikas, J., \& Grant, M. M. (2013). Mobile computing devices in higher education: Student perspectives on learning with cellphones, smartphones \& social media. The Internet and Higher Education, 19, 18-26.

Hamalik, Oemar. (2004). Teknik Pengukuran dan Evaluasi Pendidikan. Bandung: Mandar Maju.

Hanum, N. S. (2013). Keefektifan E-learning sebagai Media Pembelajaran (Studi Evaluasi Model Pembelajaran E-learning SMK Telkom Sandhy Putra Purwokerto). Jurnal Pendidikan Vokasi, 3(1), 90-102.

Heryan, Muhammad. 2020. Dampak Positif dan Negatif Pembelajaran Daring di Tengah Pandemi

COVID-19. https://www.kompasiana.com/muhammadheryan5091/5eaa9096d541df10c b598de2/dampak-positif-dan-negatif-pembelajaran-daring-di-tengahpandemi-covid-19. Diakses 21 November 2020. Diakses 10 Januari 2021

Juliansyah, Noor. 2011. Metodologi Penelitian. Jakarta: Prenada Media Group.

Juniarti, S. 2018. Pengaruh Kemampuan Berpikir Kritis Terhadap Hasil Belajar Matematika Siswa Kela V SD Dharma Wanita Pertiwi Tahun Ajaran 2018. 2019. http://portaluniversitasquality.ac.id. Diakses 20 Juni 2021.

Jones, K. A., \& Sharma, R.S. 2019. Reimagining A Future For Online Learning. SSRN Electronic Journal.

KBBI Online, 2021. https://kbbi.web.id/. Diakses 10 Januari 2021.

Kemdikbud. 2019. Surat Edaran Kementerian Pendidikan dan kebudayaan Nomor 14 Tahun 2019 Tentang Penyederhanaan Rencana Pelaksanaan pembelajaran) http://pgdikmen.kemdikbud.go.id/read-news/surat-edaran-mendikbud-nomor14-tahun-2019. Diakses 10 Oktober 2020.

Kemdibud. (2020a). Surat Edaran Nomor 4 Tahun 2020 Tentang Pelaksanaan Kebijakan Pendidikan dalam Masa Darurat Penyebaran Corona Virus 
Disease (COVID-19) http://pgdikmen.kemdikbud.go.id/read-news/suratedaran-mendikbud-nomor-4-tahun-2020. Diakses 10 Oktober 2020.

Kemdikbud. (2020b). Surat Edaran Nomor 15 Tahun 2020 Tentang Pelaksanaan Kebijakan Pendidikan dalam Masa Darurat Penyebaran Corona Virus Disease (COVID-19) https://bersamahadapikorona.kemdikbud.go.id/wpcontent/uploads/2020/05/SE-Sesjen-Nomor-15-Tahun-2020-2.pdf. Diakses 10 Oktober 2020.

Kemdikbud. (2020c). Surat Keputusan Bersama (SKB) Menteri Pendidikan dan Kebudayaan, Menteri Agama, Menteri Kesehatan, Menteri Dalam Negeri tentang Perubahan atas Keputusan Bersama Menteri Pendidikan dan Kebudayaan, Menteri Agama, Menteri Kesehatan, dan Menteri Dalam Negeri Nomor $01 / \mathrm{KB} / 2020$, Nomor 516 Tahun 2020, Nomor HK.03.01/Menkes/363/2020, Nomor 440-882 Tahun 2020 tentang Panduan Penyelenggaraan Pembelajaran pada Tahun Ajaran 2020/2021 dan Tahun Akademik 2020/2021 di Masa Pandemi Coronavirus Disease 2019 (COVID19) https://www.kemdikbud.go.id/main/blog/2020/08/penyesuaian-keputusanbersama-empat-menteri-tentang-panduan-pembelajaran-di-masa-pandemicovid19. Diakses 29 Desember 2020.

Kurniati, E., Alfaeni, D. K. N., \& Andriani, F. (2020). Analisis Peran Orang Tua dalam Mendampingi Anak di Masa Pandemi Covid-19. Jurnal Obsesi: Jurnal Pendidikan Anak Usia Dini, 5(1), 241 -256.

Martins, M. de L. (2015). How to Effectively Integrate Technology in The Foreign Language Classroom for Learning and Collaboration. Procedia-Social and Behavior Sciences. 174, 77-84.

Mulyatiningsih, E. (2011). Riset Terapan Bidang Pendidikan \& Teknik. Yogyakarta: UNY Press.

Nakayama M, Yamamoto H, \& S., R. (2007). The Impact of Learner Characterics on Learning Performance in Hybrid Courses among Japanese Students. Elektronic Journal ELearning, 5(3).195-206

Prajana, A. 2007. Pemanfaatan Aplikasi Whatsapp dalam Media Pembelajarn di UIN Ar Raniry Banda Aceh. Cyberspace: Jurnal Pendidikan Teknologi Informasi, $1(2), 122-133$.

Riyanda, AR, Herlina, K., Wicaksono, B.A., (2020). Evaluasi Implementasi Sistem pembelajaran Daring Fakultas Keguruan dan Ilmu Pendidikan Universitas Lampung. Jurnal IKRA-ITH Humaniora, 4(1).

Riyanto. (2018). Statistika Pendidikan. Bengkulu: Tidak Dipublikasikan.

Sari, P. 2015. Memotivasi Belajar dengan Menggunakan E-Learning. Journal Ummul Quro, 6(2), 20-35.

Simamora, B. (2002). Panduan Riset perilaku Konsumen. Jakarat: PT. Gramedia Pustaka Utama.

Sugiharto, et.al. (2007). Psikologi Pendidikan. Yogyakarta: UNY Press.

Utami, Y.P., \& Cahyono, D.A. (2020). Study at home: Analisis Kesulitan Kesulitan Belajar Matematika pada Proses Pembelajaran Daring. Jurnal Ilmiah Matematika Realistik (JI-MR), I(1), 20-26.

Weldan, F., S. (2019). Keunggulan dan Kelemahan Hasil Tes Belajar. https://bdkpalembang.kemenag.go.id. Diakses 20 Juni 2021.

Yudiawan, A. (2020). Belajar Bersama COVID-19: Evaluasi Pembelajaran Daring Era Pandemi di Perguruan Tinggi, Papua Barat. Jurnal Pendidikan Islam. 6(1), 10-16.

Yulianti, E. (2020). Kontekstualisme Problematika Pembelajaran Agama Islam Pada Masa pandemi Covid-19. Program Studi PAI STIT Raden Wijaya Mojokerto. Httpp://jurnal.stitradenwijaya.ac.id/index.php/pgr/article/download/270/274. Diakses 20 Juni 2021. 